\title{
Van Bevrydingsteologie na Swart Teologie in Suid-Afrika
}

Prof. Bouke Spoelstra

\section{A. BEVRYDINGSTEOLOGIE}

\section{OORSAKE}

Die bevrydingsteologie reageer teen strukture en praktyke wat die menswaardigheid van die mens en persoon aantas. Die wortels daarvan lè in Suid-Amerika en die vSA. Tog het Hitler se filosofie van die Ariërs as Herrenvolk en vervolging van die Jode die Tweede Wêreldoorlog gemotiveer. Reeds in die oorlog het Bonhoeffer aandag gevra vir die ander mens in nood. Jy moet God dien in wat jy aan die ander doen. Dr. C. F. Beyers Naudé trek reglynig 'n parallel tussen Naziisme van Hitler en "apartheid" in Suid-Afrika (Berkhof, 1985: 168).

Bevrydingsteologie sluit ook aan by die kommunistiese en sosialistiese reaksie teen armoede, honger, siekte, dood en agteruitgang wat in bepaalde lae van 'n welvarende samelewing voorkom. Die skokkende ongelykheid tussen ryk en arm in geindustrialiseerde lande en kontras tussen ryk en arm lande tas magtelose mense se menswaardigheid aan. So het 'n internasionale solidariteit ontstaan wat die ongelykheid sonde van kolonialisme en kapitalisme noem. Byvoorbeeld, hoewel die VSA die Tweede Wêreldoorlog vir Europa help wen en bv. Nederland bevry het, leef daar by jonger mense ' $n$ intense gevoel teen die vSA omdat dit ' $n$ "ryk" land is.

\section{POLITIEKE TEOLOGIE}

Politieke teologie probeer om die Christelike godsdiens en kerk binne die konteks van moderne politiek relevant te gebruik. Binne politieke teologie kom verskillende nuanses voor en verskil verder van persoon tot persoon:

- Teologie van die Rewolusie (Schaull)

- Teologie van Hoop (Moltmann)

- Teologie van Bevryding (Torres, Miquez, Gutierrez, Bonino)

- Swart Teologie in die vSA (Cone, Cleage, Roberts)

- Swart Teologie in SA (Moore, Chikane, Mosala, Thagale, Manas Buthelezi, Goba, Tutu, Boesak, e.a.).

Politieke teologie het die belangrikste rigting in veral die swart kerklike en maatskaplike lewe geword. A.g.v. die bemoeienis van die WRK en sy spruit, die SARK, infiltreer aanhangers daarvan sleutelposisies in kerklike organisasies en wend dit polities aan.

\section{BEVRYDINGSTEOLOGIE AS SODANIG}

Hierdie "teologie" het in Middel- en Suidelike Latyns-Amerika ontstaan waar vir meer as 400 jaar die sosio-ekonomiese, politieke en godsdienstige bestel uit Europa (kolonialisme) 'n skerp lyn tussen "we Europeans" en "they, the non-European natives" getrek het. Die koloniseer- 
ders en hulle bevoorregte opvolgers het alles besit en die groot massas in meer as 20 Latyns-Amerikaanse lande niks nie.

Die samewerking tussen die swaard van die Europese koloniseerder en die kruis van die Rooms-Katolieke priester het die mense verwar. Die inheemse kulturele en politieke instellings van Quechuas en Aztecs is onderdruk. 'n Magtige besittersklas het as kliek die ekonomie vir eie gewin beofen. Buitelandse kapitaalbelange het barbaarse praktyke beoefen. Militêre diktators en die wetsisteem het elementēre menseregte verkrag. Die amptenary was korrup. Die godsdiens het die rykes beskerm en armes geignoreer.

In Brasilie met sy minderbevoorregte en arm massas het biskop Helder Camara met lydelike verset probeer tuisbring dat die evangelie van Christus mense persoonlik maar ook op sosiale, politieke en ekonomiese gebied verlos indien die heersende stelsel reg en regverdig teenoor almal sou wees. Die Rooms-Katolieke priester Camilo Torres het egter lydelike verset verwerp en rewolusie deur geweld as enigste oplossing beskou. Hy sneuwel op 15 Februarie 1966 teen die regeringsmagte.

Die kerklike leiers wat met Torres simpatiseer, het Marx se dialektiese beginsel op die samelewing aangelê. Volgens Marx bestaan die samelewing uit twee klasse in gedurige klassestryd: die onderdrukker en onderdrukte, of 'n "top-dog"' en "under-dog". Die onderdrukker handhaaf sy posisie met geweld. "The fundamental law of history, which is the law of the class struggle, implies that society is founded on violence. To the violence ... of the rich over the poor, there corresponds the counter-violence of the revolution, by which this domination will be reversed" (Vatican 6.8.84 in Roberts $1986: 127$ ).

Die oorwegend Roomse teologie in Latyns-Amerika is verwyt dat dit die Bybelse boodskap van bevryding net op die individu, sy innerlike en met die oog op 'n hiernamaals verkondig het. So verkeer die "bevryde" innerlike lewe in tweespalt met die daaglikse verdrukkings van die "uiterlike lewe". Marx se model verklaar hoe die samelewing werk. Rewolusie alleen kan die hele mens en die wêreld van sy basiese teenstrydighede en nasionalismes bevry. "No-one can be free until all are free" (José Miguez).

Die bevrydingsteologie gaan basies dus van 'n eenparty-, enerse sosiopolitieke bedeling uit wat aan net een klas, die armes, behoort.

Bevrydingsteologie verwys in die eerste plek na sy "concern for the poor and victims of oppression, which in turn begets a commitment to justice". Hulle verstaan die armes waarvan die Bybel praat as sosioekonomiese armes binne 'n onderdrukkende politieke sisteem. Hulle verklaar met beroep op die Bybel dat God altyd onvoorwaardelik aan die kant van die verdruktes, die armes, is.

\section{UITSTAANDE KENMERKE VAN BEVRYDINGSTEOLOGIE}

4.1 Daar is ' $n$ basiese "commitment to the poor". Die evangelie is net vir armes en net armes kan dit verstaan.

4.2 Bevrydingsteologie implementeer ' $n$ totaal nuwe uitlegkunde (hermeneutiek). José Miquez sê jy moet die Bybel bevooroordeeld lees, "we 
must abandon our capitalistic spectacles in favour of Marxist ones" (Roberts $1986: 112$ ).

4.3 Teologie moet in 'n sosiale konteks beoefen word. Fierro sê die Bybel moet kontekstueel, deur die bril van hierdie tyd gelees word. Teologie is 'n sosiale wetenskap wat soos sosiologie, politieke wetenskappe, ekonomie ens. nie gedogmatiseer moet word nie maar dit moet gedoen word. Marx se analise is geldig: stryd tussen klasse is die krag wat alle sosiale vooruitgang motiveer.

Jesus Christus verlos die mens deur rewolusie uit ekonomiese armoede en sosiale ongelykheid wat die onderdrukkende politieke sisteem veroorsaak. Verlossing is dus sosiale en politieke bevryding. So veroorsaak rewolusie versoening of "koinonia", 'n wêreldgemeenskap as "alternative society" (sonder dat enigsins van bekering tot en gehoorsaamheid aan God melding gemaak word). Die "alternative society" is in wese 'n teologiese term vir Marx se utopia van 'n internasionale kommunistiese of neo-Marxistiese arbeidersgemeenskap.

4.4 Die bevrydingsteologie sien die kerk nie as 'n gemeenskap van gelowiges wat deur geloof saamgebind word nie. Die kerk is by hulle 'n gemeenskap van sosio-politieke profete en bevryders (vgl. Vorster 1984: 149).

4.5 Die etiek of leer oor die norme wat menslike gedrag as goed of sleg bepaal, word kontekstueel gemaak. Alles (ook geweld) wat die status quo bestry (selfs aanvalle op sagte teikens of uitsprake van peoples court), steun die rewolusie en is daarom goed. Elke verandering van die status quo beloof ' $n$ beter wêreld. Die doel heilig die middel.

4.6 God is 'n God van verandering deur rewolusie; vyand van die status quo en stagnasie; verbreker van rykes en hoogmoediges; stryder vir minderbevoorregtes, verdruktes en armes. God is 'n politieke God wat aktief stry aan die kant van die Derde Wêreld om vernuwing te bring deur middel van krisissituasies te veroorsaak (Strauss 1984:9).

4.5 Die onhoudbare plofbare toestand (die vyf-minute-voor-twaalf-sindroom) vereis ' $n$ wetenskaplike analise. Marx se model bied daardie "wetenskaplike" analise van die oorsake van die plofbare toestand. Bevrydingsteoloe ignoreer die feit dat Marx se dialektiese model van 'n klassestryd op ' $n$ ideologie berus, wat totalitêre sosio-ekonomiesepolitieke beheer nastreef.

\section{AMERIKAANSE 'BLACK THEOLOGY'}

\subsection{Die Neger-situasie in die VSA}

Die Negersituasie in die VSA kan enigsins vergelyk word met die posisie van die sogenaamde "Kleurlinge" in Wes-Kaapland. Die posisie verskil hemelsbreed van die van die swartes in Suid-Afrika wat nog grotendeels in kultuurgemeenskap en historiese "tuislande" gewortel was.

Die Negers in Amerika is as slawe uit Afrika met die oog op goedkoop arbeid ingevoer en dienooreenkomstig aan degraderende reelings onderwerp om hulle slawe te hou. Na die vrymaking van slawe wat tot burgeroorlog in die VSA gelei het, het segregasie as tweelingbroer van slawerny bly voortlewe. Dit stem tot in die sestigerjare baie ooreen met die "apart- 
heids"-reëls wat in Suid-Afrika m.b.t. kafees, toiktte, skole, kolleges en woongebiede geld en gegeld het. Die Amerikaanse kerke het geen noemenswaardige protes teen die segregasie geloods nie. Die vyandigheid van die Negers teen kerklike "apartheid" in die vSA het op 4 Mei 1969 'n kritieke hoogtepunt bereik toe James Foreman 'n erediens in New York onderbreek het en namens die Negergemeentes op 'n aandeel in die $\$ 500$ miljoen geldelike bates van die wit kerke aanspraak gemaak het. Dit sou illustreer hoe "wit kapitaliste" alles vir hulleself geneem het en die Negers met godsdiens aan die slaap gehou het om "goedkooparbeid" te eksploiteer.

Die aandag op kerklike segregasie het Malcolm X, seun van 'n Baptiste predikant, so verbitter dat hy Moslem en Angella Davis kommunis geword het. In die neerdrukkende situasie moes daar eenvoudig 'n swart kerk met 'n "swart teologie" onder die Negers ontstaan waardeur hulle hulle minderwaardige slawe-verlede kon afskud en 'n gevoel van menslike waarde kon ontwikkel en hulle dan kon optrek om aanspraak te maak op 'n gelykwaardige posisie binne die blanke vSA gemeenskap.

\subsection{Black Theology in the VSA}

Marcus Garvey (1887 - 1940), vader van "swart godsdiens", het opgemerk dat God vir die blankes "wit" is. "We negroes believe in the God of Ethiopia" en daarom was Christus "a black Man of sorrows".

Oortuig van die waarde van die swart mens het Martin Luther King jr die Civil Right Movement in the sestigerjare geloods. Hy het geweld radikaal afgewys en lydelike verset bepleit. Daarvoor is hy vervolg. meer as 20 maal in die tronk gewees, uitgeskel vir 'n kommunis, aangeval en sy huis met 'n bom getref.

Daarmee het die stryd teen "white domination" begin en by "Black Theology", Theology of Liberation en Theology of Revolution aangesluit. Ten spyte van verskille kom terminologie, aksente en beroep op Marx in baie opsigte ooreen. James Cone publiseer boeke met titels soos "God of the oppressed". "Black Theology and Black Power" en "Liberation: a Black Theology of Liberation" (1970). Daarmee neem "Black Theology" by Cone en Albert Cleage definitiewe vorm aan.

\subsection{Black Theology van James Cone}

Die leerstellings van Cone hou kortliks die volgende in:

5.3.1 Slegs die dinge wat mense in die konteks van hulle lewens ervaar kan mense as waarheid ken. Daarom ken Negers die waarheid van verdrukking wat blankes nie kan ken nie omdat hulle nie daarin deel nie. 5.3.2 God is aan die kant van en kampvegter vir die "oppressed and powerless" omdat hulle "defenseless" is.

5.3.3 God en Christus is swart.

5.3.4 Swart teologie spreek die sosiale onreg en verdrukking aan wat die lyde en nood van swart mense sedert hulle slawe-dae veroorsaak sodat hulle nog nooit vryheid geken het nie. Daarom is dit ' $n$ "liberation theology".

5.3.5 Sonde tas mense se menswaardigheid aan en kom in die maatskappy voor in rassediskriminasie, ekonomiese en politieke verdrukking. 
5.3.6 Die teologie wat sendelinge oor deugde en 'n toekomswêreld verkondig, is 'n "white lie" wat wil voorgee dat God nie betrokke is by lyde hier en nou nie.

5.3.7 Cone en Cleage verwerp Martin Luther King jr se geweldlose verset en teer op haat as middel om verlossing te bring.

Cone sê op grond van die oT (Ex 3 en 23; Amos $8: 6$; Jes $10: 1$ - 2; Lev $2: 5$; Ex $23: 3,6,10,11$ ) en die NT (Luk $6: 20,24)$ : "There can be no Christian theology which is not identified unreservedly with those who are humiliated and abused" (Cone $1970: 17 \mathrm{v}$ ). Rewolusie is derhalwe "a Christian, a priestly struggle" waarin blanke teoloë hulle tradisioneel die nood van swartes nie aangetrek het nie. Hy sè "in a racist society, God is never color blind ... he sides with the poor" (25). Hy haal Marx met instemming aan: "Freedom is the essence of man". Dit moet in die alledaagse praktyk uitkom.

\subsection{Die drie fases in Swart Teologie}

Swart Teologie is dus politieke en bevrydingsteologie, 'n proses waardeur die denke van mense geleidelik in 'n radikale koers gekondisioneer, gestimuleer en gestuur word. Die geestelike "glybaan" (Strauss 1984 : 23) verloop in drie duidelike fases:

5.4.1 Die retoriese of praat-fase maak die Bybel "relevant" deur te wys op die strukture wat rykdom en sonde vergestalt en hoe dit die ontmenste swart mens verdruk.

5.4.2 Die tweede fase volg met dade en organisasie op en lê die aksent op saamstaan en solidariteit. Verskillende organisasies moet gestig en saamgesnoer word. Die kerklike prediking moet nou al meer 'n politieke kleur aanneem en klem lè op "justifiable violence" en aandring op burgerlike ongehoorsaamheid. So word die weg vir vryheidsvegters voorberei.

5.4.3 In die derde fase word Russiese kommunisme verwerp, maar tog 'n neo-Marxistiese ideologie en praktyk met Bybelse terme geyk. Die swart teologie laat so die Bybel met Marx saamwerk.

\section{SWART TEOLOGIE VAN DIE VSA NA SUID-AFRIKA}

Die beweging vir "black consciousness, black power" en "black theology" het aan die einde van die sestigerjare van Amerika na Suid-Afrika oorgewaai. Alhoewel die situasie van die swartes in Suid-Afrika histories, kultureel, ekonomies en andersins van die in Amerika verskil het, is op die rassenoemer "swart" tog die situasies met mekaar gelykgestel. Die volgende faktore het waarskynlik daartoe bygedra:

(1) Diskriminerende "apartheids"-maatreels het in Suid-Afrika met segregasie in die VSA ooreengekom.

(2) Die SA bevolkingsklassifikasie berus op ras.

(3) Die SA Regering het wel sosio-politieke en ekonomiese regte aan die sg. "tuislande" verleen, maar die probleem van die "stedelike swarte" nie effektief aangespreek nie. Dit laat die posisie van die swartes in die SA stede met die van Negers in die VSA ooreenkom.

(4) Later is die Marx-model van armoede op die "tuislande" toegepas en skryf "black theology" dit af as 'n slim set om verdrukking en armoede te bevestig. 
(5) Linkse bewegings soos die ANC en SAKP is verbied en het ondergronds gegaan. Hulle het gevestigde organisasies en kerke geinfiltreer, veral omdat 'n regering dan nie teen kerke sou mag optree nie, soos biskop Tutu voor die Eloffkommissie betoog het (Berkhof, $1985: 56)$.

(6) Black Theology is stelselmatig by Wilgespruit beoefen en in die kerke ingedra. Toenemend is swart predikante "committed" om polities relevant d.m.v. "black theology" openlik of versigtig pohtieke verandering af te dwing.

(7) Die vakuum in inligting na die sogenaamde "inligtingskandaal" het internasionaal aan die WRK en sy lidkerke in Nederland, Wes-Duitsland en Amerika en aan die SARK binnelands ' $n$ vry hand gebied om swart kerke teologies te monster vir ' $n$ verenigde front (UDF) teen die status quo in SA.

\section{B. VAN BLACK THEOLOGY NA LIBERATION THEOLOGY IN SUID-AFRIKA}

\section{NEO-MARXISME GEBRUIK KERK EN GODSDIENS}

Marxisme is materialisties en ateisties en Russiese Kommunisme op grond daarvan anti-kerklik. Die Neo-marxisme het egter ingesien dat kerklike strukture infiltreer, gemanipuleer en gebruik kan word. Black Theology (BT) het in die VSA bewys dat Marx se analise van "onderdrukkers" (wit) en "onderdruktes" (swart) die kerk 'n stem van die "stemlose" massa maak. In Suid-Afrika kan die kerke die swart jeug alleen behou wanneer hulle verenigd d.m.v. 'n beweging soos SARK ('n spruit van die WRK) hulle identifiseer met die stryd om "liberation".

Die kerke moet aanval op die simbole van die heersende establishment soos die SAW, SAP, nasionale diensplig, politieke aanhouding en gevangenskap. Die kerk het 'n profetiese (praat) taak in fase 1 van die rewolusie en kan in fase 2 met dade soos Belydenisse en konflik met "kerkteologie" mense vir fase 3 konsolideer, wanneer die aktiewe rewolusie oorneem.

Kerke is egter groot lomp sosiale strukture. 'n Minderheid van "covenanted" kerkleiers moet deur skoling in "Black Theology" soos sout en suurdeeg in die moderature en belangrike kerklike kommissies (deeg) indring om besluite en optredes vir die massas voor te skrywe (Berkhof 1985:81 vv, 86). So kweek die kerke eenheid, betrokkenheid en broederskap (kameraadskap). 'n Mens merk die model van (marxistiese) kameraadselle in byvoorbeeld die "broederkring"'-patroon wat dr. Boesak effektief in en tussen die NGSK, NGKA, SARC (Indiers) en enkeles uit die NGK aanwend. Die "kerk" bied vir aktiviste goeie skuiling soos biskop Desmond Tutu voor die Eloffkommissie in die ondersoek na die SARK betoog het. Hy ontsê die Regering enige bevoegdheid van oordeel in kerklike sake omdat dit neerkom op 'n blinde wat 'n blommeskou beoordeel. Die kerk maak vir homself uit wat hy onder reg, geregtigheid, vrede, versoening, medelye, ens. verstaan. Daarbenewens kan 'n blanke Eloffkommissie volgens Tutu nie oor swartes oordeel nie, omdat hulle nie die honger, vrees, ondervoeding en ellende van swartes 
kontekstueel aan eie lywe ondervind nie (Berkhof $1985: 56 \mathrm{v}$ ). Indien Black Theology (BT) soos hier betoog word, 'n bepaalde politieke ideologie wil uitdra om 'n sosialistiese ekonomie en staat te stig (Mosala, Thagale $1986: 19,22 \mathrm{v}, 162$; Berkhof $1985: 86 \mathrm{v}$ ), bied kerke en godsdiens 'n soort onaantasbare skuilplek en openbare arm om polities-ekonomies aan te wend.

\section{UNIVERSITY CHRISTIAN MOVEMENT EN BLACK THEOLOGY PROJECT}

Die blanke Metodiste predikant Basil Moore, sekretaris van UCM, het by die Wilgerspruit Fellowship Centre ongeveer in 1971 doelbewus en openlik in 'n Black Theology Project (BTP) die teologie van Cone, Cleage en andere uit die VSA aangegryp om ook in Suid-Afrika "black consciousness" te stimuleer (Moore 1973 : vii, 1 ev, 48v; Mosala, Tlhgale $1986: \mathrm{xi}, 38 \mathrm{v}, 62$ ). Die verskillende swart "nasionalismes" en trots van Zulus, Xhosas, Sothos e.a. ontbreek totaal in die VSA onder die Negers. Tog het die wyse waarop burokrate etnisiteit met die oog op "apartheid" toegepas het om mense te verskuif, van brood en botter in die stede te weer, veroorsaak dat etnisiteit toenemend beskou is as 'n set ter wille van blanke selfbehoud. Die afsonderlike swart tuislande sou beoog om swartes lewe in die stede te ontsê en te dien as plekke waar swartes ge'dump' en gevange gehou kan word. Toe die eerste direkteur van BTP, Sabela Ntwasa, in 1973 onder huisarres geplaas is en die Regering 'n ondersoek na die Wilgerspruit Fellowship Centre gelas het, het Moore na Engeland gevlug en die UCM by voorbaat ontbind. 'n Voormalige kandidaat vir Roomse priesterskap, M. Motlhabi, het Ntwasa opgevolg. Die publikasie Essays on Black Theology is in die ban gedoen. Motlhabi en dr. Manas Buthelezi het met 'n Black Theology Movement by SASO van Biko probeer inval. So is te Hammanskraal saam met die Christelike Instituut verklarings teen diensplig ens. uitgereik. In 1975 is die laaste byeenkoms in Lesotho gehou (Moore 1973 : xi, Mosala, Thagale 1986 xi - xv).

\section{BLACK THEOLOGY HERLEEF VANAF 1978}

Allan Boesak se boek Farewell to Innocence (1978) en werk van die Lutherse dr. Manas Buthelezi en dr. B. Goba van die United Congregational Church word as baanbrekers vir 'n meer akademiese Black Theology in Suid-Afrika geroem (Mosala, Tlhgale 1986 : xiii - xv, 47). Daar word duidelik tussen fase 1 en 2 in die ontwikkeling van BT onderskei (Mosala, Tlingale 1986 : xiii, xv, 54).

In die eerste fase het Moore Marx se analise in rassekategoriee toegepas en soos Cone in die VSA aangeval op die "white dominated power structures". Hy het die ideaal van 'n multi-racial samelewing waarin wit en swart deur "reconciliation" saamleef, wat destyds deur Engelse geestelikes bepleit is, verwerp. Hy noem dit 'n poging om opkomende swart leiers van die "illiterate, poor and starving black masses" te vervreem en hulle "leaderless" te laat. "Courting with whites, they have lost contact with the poor blacks". Die Engelse wit establishment was al lank voor 1948 verantwoordelik vir die ellende onder swartes. Moore beskryf die Soweto-ghetto met die vrees wat daar heers om uitgeskop te word, nie 'n pas te hê nie, armoede, koue en honger te trotseer en babas wat van ondervoeding sterf as gevolg van die "verdrukkende" stelsel (Moore 
1973 : 4v). Opmerklik genoeg gebruik Tutu en Boesak hierdie beskrywing 'n dekade later feitlik nog net so (Berkof $1985: 59,69$ ).

Motlhabi, Chikane, Goba en ander nuwe "teoloë" soos Sebidi, Mofokeng, Mosala, Maimela, Thagale kom uit verskillende kerklike groeperinge maar verenig vanaf Augustus 1983 om BT in fase 2 te laat herleef en verwag van fase 2 ' $n$ agenda om tot dade oor te gaan. BT sluit nou ook agter die VSA aan by die Liberation Theologies van Latyns-Amerika en feministiese Liberation Theology in die Weste. Die konflikmodel van Marx se samelewingsontleding word nou doelbewus vir die beoefening van hierdie teologie aanvaar (Mosala, Thagale 1986 : xiii - $x v$ ). In nou verband met BT staan die Institute for Contextual Theology, waarvan Frank Chikane, die "selfless Christian activist and subject of the black struggle for liberation", die direkteur is (Mosala, Thagale 1986 : ix).

Boesak maak ook klaarblyklik van die Marx-model gebruik wanneer hy sê: "God se goeie nuus vir die armes is slegte nuus vir die rykes". Hy hou eerder die ekonomiese sisteem as apartheid vir armoede in SuidAfrika verantwoordelik omdat die rykes daarmee vasklem om te hou wat hulle het (Berkhof $1985: 66-69$ ). Hy beloof dus om 'n landwye dag van gebed uit te roep waarin om die val van die Regering gebid sal word. So lank die Regering vasklem aan die kapitalistiese stelsel is al sy "hervorminge" sinloos. Suid-Afrika benodig 'n "kwalitatief ander samelewingstelsel" ( Ibid: 69, 70 v). Hiermee word eintlik gesê dat daar primêr nie op uitskakeling van diskriminasie teen swartes nie, maar op 'n sosialistiese stelsel vir "armes" afgestuur word. Boesak noem die omkeer van die bestaande orde God se droom vir die "wêreld". Wêreld is meer as "Suid-Afrika". Die begin van fase 2 van BT val nie verniet met dag en datum in Augustus 1983 saam met die stigting van UDF en kerklike belydenisse in die NGSK van dr. Boesak nie.

\section{DIE AKSENT IN BLACK THEOLOGY VERSKUIF VAN RASSEKONFLIK NA KLASSEKONFLIK}

Wanneer 0.a. Motlhabi in 1973 "liberation of the black man" bepleit, druk hy hom soos Moore in rasseterminologie uit: "To be black in our country means first to be a victim of apartheid and the object of colonisation, disinheritance and exploitation ..." (Moore 1973 : 74 - 76). So het Moore ook die swart Messias verkondig: "Jesus was, though oppressed, a liberator of the oppressed. Belonging to the oppressed, Christ is black. But he cannot be a black uncle Tom. Christ is Black (with a capital B) i.e. the one who is identified with the blacks . . . This indicates clearly that the passionate concern of Black Theology is with Liberation, with Freedom . . . God is Freedom . . . Thus Black Theology is a passionate call to action for freedom, for God, for wholeness of man" buite die magswellus van die outoritère blanke om (Moore $1973: 8 \cdot 10$ ).

Motlhabi het egter reeds destyds aan "black" 'n figuurlike en wyer betekenis probeer gee asof dit alle "oppressed people" aandui "irrespective of colour . . nationality and creed" (Moore 1973: 77), maar die nadruk het op die swarte in 'n "apartheid"-bestel in kontras met die bevoorregte heersende "blanke" bly val. Voorstanders van BT wat "apartheid" aanval wil Christus in SA soos in die vSA swart voorstel, 
'n plakker in die Kaapse vlakte, 'n "nie-blanke" in Soweto, wat onder 'n paar sinkplate of kartondose inkruip, van droe brood en Coca-Cola leef, 'n pas dra, by die agterdeur van die witbaas aanklop, koffie uit sy jêmblik drink, die Groepsgebiedewet aan eie lywe voel. Hy moet drieuur in die môre deur die polisie wakker geskop word en weet hoe dit voel om deur die blankes soos 'n lemoen uitgedruk te word en dan sielsmoeg met 'n bottel wyn teen sy kaia te val. Sy godsdiens sal egter vir hom relevant word, wanneer dit hom help om uit die verdrukking van apartheid op te staan (Strauss $1984: 1$ ).

Wanneer Black Theology in 1983 herleef, moet die "purpose en goal" in terme van "liberation, justice and peace" en nie meer as 'n stryd van swart teen wit nie, uitgespel word (Mosala, Tlhagale 1986 : xix). Nee, hulle sê "black people were ... to draw the liberation struggle to the very centre of capitalist ideology, namely the Christian theological realm" en aanval op die "economic substructure of Western capitalism" wat die "ruling class" beoefen. Dit gaan om 'n klassekonflik en nie 'n rassekonflik nie (Ibid vii, viii). Hulle beweer dat blankes kapitalisme slegs met rassisme, seksisme, buitelandse kapitaal, multi-nasionale maatskappye sowel as die nuwe ideaal van 'n federale politieke bestel verskans.

So erken BT "two conflicting kinds of analysis" wat "black opposition" oënskynlik in twee onversoenbare kampe verdeel. Sommige voer 'n rasse- en ander 'n klassedebat (Ibid $1986: 2$ ). Die rassedebat word deur bewussynsgroepe of radikales soos SASO, PAC en andere gevoer. Die meer liberale groepe soos die ANC en UDF staan 'n "integrationist and multi-racialist" samelewing voor. Die blanke rassisme was net 'n "function of capitalist exploitation ... In short the face of the problem is racià, but its essence non-racial" (vgl. Sebidi in Ibid: 13-22).

Dit is dus die nuwe taak van BT om die stryd uit die konteks van wit en swart te lig en as 'n stryd van werkers-teen-kapitaliste verder te voer. Werkers is oral werkers en kapitaliste is oral kapitaliste. 'n Stryd van swart mense teen witmense, sluit binnelands en buitelands wit werkers van hulle stryd uit. In hierdie stadium verwys BT nou ook uitdruklik na die Bevrydingsteoloë soos Gutierrez en Bonino in Suid-Amerika. Swart solidariteit alleen sal nie wit kapitalisme verslaan nie. Die werkers uit alle rasse benodig "a broad plan of action to achieve a socio-political blueprint, namely an anti-racist, socialist Azania" (Ibid tap). Gevolglik val die taak op BT vanaf 1983 " to ferret out the fundamental differences, dissimilarities" tussen die aanvanklike vertolking van die Marx-konflikmodel in Suid-Afrika in terme van swart teen wit (soos wat dit in die vSA die geval was) en die toepassing daarvan deur sosialistiese en kommunistiese partye, naamlik, as 'n konflik tussen die werkers en die kapitaliste.

Black Theology het verder die taak om kerkleiers uit die mees uiteenlopende groeperinge saam te snoer. So kan Allan Boesak van die NGSK, Motlhabi en die aggressiewe Tlhagale uit die Roomse Kerk, Lutherane, Anglikane, Metodiste, Beyers Naudé en blanke predikante uit die NGKfamilie, Chikane van die AGS, Goba van die United Congregational Church en nog baie meer ideologies heg saamgesnoer word. Die 152 
ondertekenaars van die sogenaamde Kairosdokument in 1985 bewys hoe effektief hierdie interkerklike konsolidering met een en dieselfde prioriteit en doelwit voor oe plaasvind. BT word dus doelbewus vanaf 1983 in die rigting van Liberation Theology gestuur om 'n omvattende sosiopolitieke sisteemverandering in Suid-Afrika te bewerkstellig.

\section{BEVRYDINGSTEOLOGIE EN DIE UNITED DEMOCRATIC FRONT}

Op die kongres van die WBGK (WARC) in Ottawa 1982 is die inisieerder van fase 2 van BT (Mosala, Thagale 1986 : xiii), dr. Allan Boesak, op taamlik opsigtelike wyse in die voorsitterstoel van die liggaam ingerangeer. Ek kon in die weke voor die Kongres in Nederland uit gesprekke met dr. A. Kruyswyk, ekumeniese amptenaar van die GKN, 'n intense belangstelling in die naderende Kongres met die oog op die Afrikaanse Kerke opmerk. Ek neem aan dat hy en ander (uit kringe van of die WRK of WGBK) nie onbekend was met die orkestrasie van die kongres se voorsitter en handeling om die twee Afrikaanse lidkerke nl. die NGK(SA) en NHKA uit die WBGK te ban en aan te stuur op die sogenaamde status confessionis (met sy suggestie van 'n anti-naziistiese verklaring soos te Barmen in 1934) waarin "apartheid" tot kettery verklaar moes word.

Frank Chikane sé egter dat bepaaldelik die konstitusionele hervormingspogings van die SA Regering (die Driekamer-parlement en voorgestelde demokraties-verkose swart Gemeenskapsrade) in hierdie stadium die Bevrydingsbeweging ernstig bedreig het. Dr. Boesak het gevolglik op 'n Indiërkongres, 21 Januarie 1983 'n oproep gedoen dat daar 'n UDF in die lewe geroep moet word om effektief weerstand te bied. Die UDF is op 20 Augustus 1983 gerealiseer met die uitdruklike doelstelling van "een regverdige onverdeelde multi-rasiale en demokratiese Suid-Afrika". Die ooreenstemming met die ANC is duidelik. As beskermhere is weer eens uiteenlopende kerkleiers soos dr. Boesak, biskop Tutu, dr. Beyers Naudé en fr. Mkhatshwa benoem. Daar is dadelik met intensiewe politieke skoling, aktivering en organisering van massale boikotte teen die verkiesing begin en mense is voorgeskryf hoe hulle moet optree (Berkhof 1985 : 86v, Chikane. Vgl. Mosale, Thagale 1986 : viii oor verset teen konstitusionele hervorming). Alhoewel daar onder 'n demokratiese vlag vir "one-manone-vote" (Mosala, Thagale 1986 : 143; Gemeenskapsrade vgl. 136v) gepleit word, is die uitgangspunt dat alle swartes of alle werkers verdruk word duidelik totalitêr en sou eenvoudig van intimidasie gebruik gemaak moes word om die "eenheid" en "solidariteit" voor te tower.

Die politieke alternatief wat vir Suid-Afrika nagestreef word, word nie so duidelik uitgespel nie. Wanneer dit hulle pas, sê teoloe selfs dat dit nie op die weg van die "kerk" lê om politieke bloudrukke te lewer nie. Tog het 'n prominente leier in BT, Tlhagale, volkome duidelikheid dat "the present exploitative capitalist system ought to give way to a more equitable socialist system that will develop an economic programme with the view to making amends in those areas where the apartheid economic system has simply played havoc and left in its wake human misery" (Mosala, Tlhagale 1986 : 143). Ook het leiers soos biskop Tutu, dr. Boesak, dr. Beyers Naudé en andere hulle herhaaldelik ten gunste van 'n sosialistiese staat uitgespreek. Biskop Tutu skryf self nie baie nie. 
maar wel 'n voorwoord as sekretaris van SARK vir die neo-marxistiese werk van Oswald Hirmer (1981) oor Marx, Money and Christ. Die beoogde meerderheid in die sogenaamde "meerderheidsregering" word nie in vrye politieke partyverdeling in 'n multi-rasiale staat nie, maar as 'n rasgegronde "swart" regering bepleit. Wêreldwyd word begrippe soos "democratic", "majority rule", "people's Congress", "people's republic" deur kommuniste gebruik om 'n totalitêre een-party "werkers-staat" teenoor kapitaliste aan te dui. Dit lyk dus asof die hervormingspoging van die Regering, wat die swart en gekleurde bevolkingsgroepe kon verdeel, BT as Liberation Theology na vore laat tree het met die oog op die daarstelling van 'n sosialistiese staat.

Die diens wat BT aan 'n sosio-politieke revolusie kon bewys, is duidelik uitgespel. Dit snoer teoloë saam, moet moderature en sleutelkommissies van kerke infiltreer en die "regte besluite" orkestreer (Strauss 1984 : 29; Berkhof $1985: 81$ ). Die patroon van die Broederkringe (Belydeniskringe) wat $\mathrm{dr}$. Boesak onder predikante en onderwysers gestig het, herinner nogal sterk aan die kameraadselle wat die marxisme gebruik. Druk kon dadelik op die NGSK vir 'n nuwe Belydenis en vir 'n verklaring dat "apartheid" 'n teologiese "kettery" is, geloods en verhoudinge tussen NGSK en NGK plotseling tot 'n breekpunt gevoer word. In 'n bundel opstelle in Nederlands, aangebied aan dr. Beyers Naudé (1985), skrywe Boesak oor "God van de armen", Chikane oor die stryd van die UDF, en Shun Govender, Bethge, Berkhof sowel as dr. C. F. Beyers Naudé oor 'n "belydende kerk" in Suid-Afrika. Die ooreenkoms hiervan met die orkestrasie van die kongres van die WBGK in Ottawa 1982 is duidelik (vgl. Naude in Berkhof 1985:169). Dit val ook baie duidelik saam met die sogenaamde fase 2 van die bevrydingstryd (Mosala, Thagale 1986 : xiii).

Wanneer Chikane die strategie van die UDF uiteensit om op "versoek" van COSAS, AZASO en NUSAS (Berkhof 1985 : 89) skoolboikotte te orkestreer en swart verkiesings te verongeluk, sê hy dat die negatiewe reaksie van die Minister van Justisie binnelandse en buitelandse steun vir UDF laat toeneem het. Die feit dat die Regering geweld teen die aksies van die UDF gebruik, dwing die vraag na vore of geweld nie ook teen die Regering gebruik moet word nie (Ibid $89 \mathrm{v}$ ). Hy verswyg in die Nederlandse boek die wrede halssnoermoorde en gewelddadige intimidasie van swartes wat met die UDF en hulle ideaal vir die toekoms verskil.

Die Roomse priester Thagale (en by implikasie die Black Theologygroep) regverdig die wrede geweld teen die polisie en by implikasie teen diegene wat 'n vrye-mark-ekonomie, 'n konstitusie wat minderheidsregte beskerm, voorstaan en 'n sosialistiese staat afwys (Mosala, Thagale 1986 : $135 \mathrm{v} ; 156)$. "Revolutionary consciousness, another name for faith, is precondition for a collective awakening . . . liberation from capitalist racist oppression and exploitation . . . Black Theology, as a theology of revolution directed against the evils of capitalism and racism, necessitates the underlying emphasis on physic liberation and internal transformation, a prerequisite for militant revolutionary change." (Kunnie in Mosala, Thagale 1986 : 153, 156). Die kerke in UDF (Berkhof 1985: 92) en BT moet die hart aan die militante fisieke bevryding verskaf. Die leiers van BT beskou COSATU (Congress of SA Trade Unions) saam met UDF as 
hulle bondgenote met die oog op "more resistance from the working class as the rethoric of a socialist alternative begins to take root" (Mosala, Thagale 1986 : viii). Dit sê onmiskenbaar dat Black Theology 'n bepaalde ekonomiese en politieke ideologie onderskryf en die vrye-marksisteem as kapitalisme verwerp.

\section{BLACK THEOLOGY EN GEWELD}

J. R. Cochrane waarsku dat BT nie te veel moet verwag van "belydenisse", "skuldbelydenisse" en oop gesprekke nie (die weg waarop die WBGK veral die NGSK en sommige uit die NGK gevoer het). Dit dien egter om 'n neo-marxistiese konsolidasie oor rasgebonde nasionalismes heen te bevorder (Berkhof 1986: 82). Resente "Essays in Black Theology" onder die titel "The Unquestionable Right to be free" (1986) val min op Suid-Afrikaanse "apartheid" aan maar fokus op die vrye-markstelsel en kapitalisme in Suid-Afrika, die VSA, Wes-Duitsland en Engeland sowel as op multi-nasionale maatskappye soos IBM, Mobil, ens. (Mosala, Thagale $1986: 16,144$ ).

Black Theology argumenteer dat geweld deel en fondament is van die lewe. Volgens Marx is die samelewing op konflik tussen klasse gebou. So is daar die strukturele/psigologiese en fisiese geweld waarmee die establishment hom handhaaf. Daarteenoor is daar geweld wat uit neerdrukkende strukture bevry. Mense in Suid-Afrika staan volgens BT onwillekeurig aan een van die twee kante. Hulle kies vir geweld van of die bevryder of hulle kies vir geweld van die onderdrukker (Strauss $1984: 7 \mathrm{v})$.

Thagale vereenselwig geweld van die bevryder met geweld teen die SAP en SAW wat die kerke met kapelaansdienste ondersteun. Jong mense het maar net eiendom en besighede verwoes van mense wat die verdrukkende sisteem steun. "But what seems to be a senseless destruction of life and property, of schools and buses and delivery vehicles - is in fact seen by blacks, especially young people, as an agressive statement of a radical protest, a self-affirmation, a calculated tactic to compel the government te reckon with the frustrated aspirations of black people" (Mosala, Thagale $1986: 137,141$ ). SA is in 'n toestand van burgeroorlog en die "merciless killings" is eenvoudig deel van die aanval op 'n gewelddadige "apartheidsisteem". Dit is 'n "evil system, minority rule, ruling clique, devils army, unjust regime" wat die blanke kerke se steun geniet.

\section{BLACK THEOLOGY EN NUWE BELYDENISSE}

Volgens Shun Govender, Sekretaris van die Belydende Kring, moes die "woord" van betrokkenheid (fase 1) in die stryd teen die offisiële kerk en staat omgesit word in gemeenskaplike dade. Die opstel van 'n Belydenis, verklaring van "apartheid" (en daarmee die vrye markstelsel) as kettery, die uitroep van die status confessionis, vorm alles deel van die aanval op die "offisiële kerke". Die Afrikaanse kerke moet kennis neem dat God die kant kies van die armes en verdruktes (Berkhof 1985: $99-101)$. Die NGSK het in 1984 die Bellhar Belydenis die lig laat sien. In September 1985 is die Kairos-dokument gepubliseer wat in 1986 hersien is. Die dokument en trouens baie van die feiteverwysings van BT na swak toestande onder swart mense moet Christene as 'n noodkreet hoor 
(Du Plessis 1987：8; vgl Vorster 1984 : 177 v, 163 v). Die Kairos-dokument analiseer die SA samelewing soos BT dit doen. Die "minderheidsregime" is 'n tiran wat 'n skrikbewind voer. Die offisiële kerkteologie is 'n staatteologie terwyl 'n "profetiese teologie" nodig is. Die profesie wys in terme van Marx se model na 'n ongedefinieerde alternatiewe samelewing. Die Transvaal Kairos Liturgy Group het in Maart 1986 vanuit Braamfontein gebeds- en preeksketse vir "church activities" gesirkuleer om dit relevant te maak "to the poor and oppressed" en in diens te stel van die "liberating mission of God and the Church in the World."

Die eerste preek het as tema: "Jesus Victim of oppression" en word uitgewerk: Jesus is deur polisie gevang; Judas was 'n "informer". Hy is ondervra en in 'n tronk gemartel. Daar was staatsgetuies. Hy was nie bang vir die regter nie, ens. Die konklusie is dat hy doodgemaak is "because in the name of God he sided with the poor and the oppressed and opposed their oppressors . . . He was killed violently."

Die tweede preek: Huil oor julleself en julle kinders. Die "suffering Christ" praat oor die "sufferings of the people in the townships and especially about the sufferings of our children . . . He suffered in solidarity with us. We suffer today in solidarity with him".

Die gebedsketse vra waarom God hulle in SA verlaat en aan vervolging en onderdrukking oorgegee het. Hulle moet bid om krag "in our struggle for justice, liberation and peace". Voorbidding moet gedoen word vir die "students" in die "school boycotts", werkloses, verandering van Regering - en "victory over our enemies".

Die derde preek: Die Here het opgestaan! Daar is hoop vir Suid-Afrika. "We are the people of the resurrection ... We hope for a speedy victory over our enemies who oppress and exploit us . . . Victory is certain . . . There is no true hope without action."

Die laaste preek handel oor "The just are rising from the tombs". Die "just" val volkome saam met die "verdrukte swart mense" in SA wat besig is om hulle waardigheid en trots te herwin. Die "resurrection" wat vandag in SA plaasvind, is die "liberation to all the people in SA oppressed and oppressor". Die "oppressor" kan hiervolgens slegs bevry word wanneer 'n neo-marxistiese politieke en ekonomiese stelsel die huidige vervang het. Ek vestig net die aandag daarop dat die sin en betekenis van Jesus se lyde en opstanding volkome op die "diesseitige", hier en nou, van die ekonomiese-politieke utopia wat die rewolusie beloof, saamgetrek word. Trouens, BT wys 'n "pie in the sky" (Mosala, Thagale 1986 : 107) uitdruklik af.

\section{KONKLUSIE}

Bevrydingsteologie is dus 'n politieke "bevrydings"'teologie wat op die ideologiese uitgangspunt van neo-marxisme geskoei is. Al die elemente en strategie van politieke teologie wat Vorster $(1985: 59-75)$ by die Christelike Instituut, WRK en SARK onderskei t.o.v. sosiale analise, bevryding, geweld, burgerlike ongehoorsaamheid, weiering van diensplig, disinvestering en herverdeling van rykdom, speel in die hart van BT en Liberation Theology mee. Al is dit duur, die land moet volgens BT on- 
regeerbaar gemaak word (Mosala, Thagale 1986 : 142). Hoewel hulle Marx se model van klassestryd verkies wanneer dit hulle pas, maak hulle onbeskaamd gebruik van die emosionele dinamiek wat in die swart-teenwit konflik opgesluit lê om van fase 2 na fase 3 (neo-marxistiese rewolusie) te kan oorgaan. "Swart" teologie moet dus al meer "denasionaliseer" om die enigste "regverdige maatskappy" wat (met geweld?) vrede waarborg (vgl. Mosala, Thlagale 1986:17), globale sosialisme, solidêr met die internasionale arbeidsorganisasies (bevryding), te bewerkstellig. Die Bybelse terminologie, selfs die naam van God, word gebruik om die neo-marxistiese ideologie te propageer.

"Patriotic churchmen like Allan Boesak, Frank Chikane and Bishop Tutu ... have defied all odds and stand firm on the side of the oppressed". BT onderskryf die vier pilare van die ideologie van die rewolusionêre stryd:

(a) Die betrokkenheid van die bevolkingsmassa by die rewolusie (studente, vakbonde, kerke);

(b) leierskap in die ondergrondse geledere van die ANC en UDF;

(c) gewapende stryd van die bevrydingsleers (peoples army);

(d) Internasionale isolasie van SA en ondersteuning uit die buiteland vir die bevrydingsstryd (VVO, WRK, en sy filiale vgl. Oktober ' 46 , Jg $1 \mathrm{Nr} 3$ ).

\section{KRITIEK OP BEVRYDINGSTEOLOGIE}

Elke eksponent van Bevrydingsteologie praat vanuit sy eie hoek en weerspieel teenstellende teologiese tradisies soos bv. Protestantisme en Rooms-Katolisme, so erg dat of die diskriminerende maatreels in "apartheid" of die suigkrag van Marx en sosialisme selfs mense uit die NGSK totaal van die NGK vervreem en in teologiese vreemde geselskap laat beweeg.

1 Die Bybel vra in OT en NT aandag vir die mens in armoede, fisiese nood, verdrukking en ellende. Hierdie waarheidsmoment het ons as Christene binne die vrye-marksisteem, kapitalisme en diskriminerende "apartheids"-wette wat mense se waardigheid en regte m.b.t. beweging, woonplek, werkplek, indiensneming ens., aangetas het, te maklik links laat lê. Die gevestigde blanke kerke het op sosiale-ekonomiese gebied nie dramaties presteer nie. Eiebelang het deurgaans oor sosiale belang geheers. Piëtisme het die godsdiens dikwels wêreldvreemd gemaak en op die hiernamaals laat saamtrek. In so ver die Bevrydingsteologie op misstande wys, speel hul 'n positiewe rol om gesonde verandering te bewerkstellig. Tog lyk dit nie asof 'n gesprek met die neo-marxisme moontlik is nie. Hulle basis en vertrekpunt is nie onderhandelbaar nie.

2 Indringende teologiese kritiek kan op die Bevrydingsteologie uitgeoefen word. Vorster (1984) wys op hulle nuwe uitlegkunde (hermeneutiek) wat die koninkryk van God in terme van die sosio-politieke en ekonomiese konteks verklaar; die neo-marxistiese verlossingsleer oor sonde, Christen, bevryding, versoening en bekering wat nie in die Bybel steun vind nie; die nuwe leer oor die kerk wat die volk van God sito-sito met die armes en polities-verdruktes vereenselwig; die nuwe etiek wat liefde loen en geweld aanprys wat verdruktes bevry. 
J. A. Heyns (sj) kritiseer die Kairosdokument se "sekularistiese teologie" wat nie die bose nie maar die "tirannieke wat minderheidsregering in SA" inhou as oorsaak van sonde aandui, staatsgesag word in stryd met Rom 13 "van onder" afgelei; die naam van God en sy "goddelikheid" word deur die welvaart van die volk bepaal; die "materialistiese neo-Marxistiese idioom" verplaas die Bybelse idioom (vgl. ook Du Plessis e.a. 1987). Die Bevrydingsteologie gaan ook mank aan "universalisme" (Christus het vir almal gesterf) en verlossing deur eie werke wat Roberts aan die sterk invloed van Rooms-Katolieke teoloë toeskryf (1986:113v).

3 Marx analiseer die samelewing as 'n voortdurende stryd tussen 'n klas van onderdrukkers teenoor 'n klas van onderdruktes. Volgens die ideologie dra die samelewing voortdurend konflik, stryd en oorlog in homself (Du Plessis $1987: 19,26,40$ ). Hierdie basiese uitgangspunt kan nooit "Christelik" genoem word nie.

Om ryk en arm, kapitalis en werker teenoor mekaar in konflik te stel en dit vir net een op te neem, skreeu eenvoudig teen die Bybelse analise van geloof en ongeloof, gehoorsaamheid en ongehoorsaamheid en die Tien Gebooie as die wet van liefde.

Bevrydingsteologie praat baie van "vryheid", "demokrasie", "geregtigheid", en 'n regverdige samelewing. Die uitgangspunt van die Bevrydingsteologie stuur egter onafwendbaar af op 'n totalitêre en een-partystaat waarin die "onderdruktes" oorneem. Bevrydingsteologie laat dus geen ruimte vir verskillende politieke oplossings, die reg om te verskil, regte van minderhede, vrye onderneming of 'n selfstandige plek vir skool, kerk en teologie nie.

Die verpolitiseerde "teologie" dien die politieke party. Eventueel beheers die politieke party persoonlike en huislike vryheid saam met alle ander samelewingsverbande.

In lyn hiermee wys dr. Boesak maatreëls ten behoewe van die armes in ' $n$ ander stelsel af en dring hy aan dat die "magteloses" mag moet oorneem en 'n "kwalitatief andere maatschappij" daarstel (Berkhof 1985 : 68 - 70). Bevrydingsteologie maak kerk en godsdiens 'n gesekulariseerde agterryer van 'n bepaalde sosio-politieke ideologie en party. Tereg sê die Roomse Vatikaan dat "certain formulas are not neutral, but keeping the meaning they had in the original marxistic doctrine. This is the case with the 'class-struggle'. This expression remains pregnant with the interpretation Marx gave it ..." (Vatican Rome 1986 : 126).

Die sosio-politieke oplossings van Bevrydingsteologie bly daarom materialisties (soos Marx basies glo), menslik, tydelik, eindig en vol foute. Dit kan nooit werklike godsdienstige behoeftes bevredig nie (Roberts 1986 : 114). Die mens sal van brood alleen nie lewe nie.

Die Bevrydingsteoloë kan nou al begin om skuld te bely vir die onreg wat hulle doen en nog gaan doen teenoor baie mense vandag en teenoor diegene van wie hulle vandag so maklik "belydenis van skuld" op grond van "apartheid" eis. 


\section{BIBLIOGRAFIE}

Arscott, L. A. 1986. Black Theology. Evangelical Review of Theology. 10 (2) April 1986, $137 \mathrm{ff}$.

Berkhof, H. L. (et al) 1985. Met de moed der hoop. Opstellen aangeboden aan Dr. C. F. Beyers Naudé. Baarn: Ten Have.

Cone, J. 1970. Liberation: A Black Theology of Liberation. Philadelphia : Lippincott.

Du Plessis, A. J. (et al) 1987. 'n Reformatoriese Kommentaar op die Kairos-Dokument. Potchefstroom: IRS.

Heyns, J. A. sj. Die Kairos-Dokument. Enkele Kritiese Opmerkinge (ongepubl).

Hirmer, O. 1981. Marx, Money and Christ. Salisbury: Mambo Press.

The Kairos-Document October 1985: Challenge to the Church. A Theological Comment on the Political Crisis in South Africa. Braamfontein.

Moore, Basil (Ed) 1973. Black Theology: The South African Voice. London: Hurst Co.

Mosala, I. J., Thagale, B. (Ed) 1986: The Unquestionable Right to be Free: Essays in Black Theology. Johannesburg: Skotaville.

October '46: Kwartaalblad van die Sentrum vir Reformatoriese en Kontemporére studies. Oktober 1986, 1 (3).

Roberts, W. Dayton 1986: Liberation Theologies: Looking at Poverty from the Underside. Evangelical Review of Theology April 1986, 10(2).

Southern Transvaal Kairos Liturgy Group March 1986 Kairos Liturgies. Braamfontein.

Strauss, P. D. 1984. Van Moses tot Marx: Swart Teologie meer bepaald binne die kring van die Ned. Geref. Kerke. Pretoria: NGKB.

Vatican Rome 1986 (Paul II 6.8.1984) : Instruction on certain aspects of the Theology of Liberation. Evangelical Review of Theology April 1986 10(2):115 ff.

Vorster, J. M. 1984 Die Neo-Marxistiese politieke Teologie in Suid-Afrika: 'n Gereformeerd-Apologetiese studie. Ongepubliseerde proefskrif vir D Th. PU vir CHO. 